Бахматов П. В., Мазур С. П., Муравьёв В. И., Ковалёв В. А.

ИССЛЕДОВАНИЕ ВЛИЯНИЯ ЧАСТОТЫ ИМПУЛЬСА СВАРОЧНОЙ ДУГИ НА СТРУКТУРУ И СВОЙСТВА СВАРНЫХ СОЕДИНЕНИЙ ЭЛЕМЕНТОВ АЛЮМИНИЕВЫХ ТРУБОПРОВОДНЫХ СИСТЕМ, ВЫПОЛНЕННЬХ НА УСТАНОВКЕ МАSTЕRТІG 3500

Бахматов П. В., Мазур С. П., Муравьёв В. И., Ковалёв В. А.

P. V. Bakhmatov, S. P. Mazur, V. I. Muravyev, V. A. Kovalev

ИССЛЕДОВАНИЕ ВЛИЯНИЯ ЧАСТОТЫ ИМПУЛЬСА СВАРОЧНОЙ ДУГИ

НА СТРУКТУРУ И СВОЙСТВА СВАРНЫХ СОЕДИНЕНИЙ ЭЛЕМЕНТОВ

АЛЮМИНИЕВЫХ ТРУБОПРОВОДНЫХ СИСТЕМ, ВЫПОЛНЕННЫХ

HA УCTAHOBКE MASTERTIG 3500

\title{
STUDY OF ARC IMPULSE FREQUENCY EFFECT ON THE STRUCTURE AND PROPERTIES OF WELDED CONNECTION ELEMENTS IN ALUMINIUM PIPELINE SYSTEMS, MADE WITH MASTERTIG 3500
}

Бахматов Павел Вячеславович - кандидат технических наук, доцент кафедры машиностроения и металлургии Комсомольского-на-Амуре государственного технического университета (Россия, Комсомольск-на-Амуре). E-mail: mim@knastu.ru.

Mr. Pavel V. Bakhmatov - PhD in Engineering, assistant professor of Komsomolsk-on-Amur State Technical University (Russia, Komsomolsk-on-Amur). E-mail: mim@knastu.ru.

Мазур Сергей Петрович - кандидат технических наук, главный сварщик филиала ПАО «Компания “Сухой” "КнААЗ им. Ю. А. Гагарина"» (Россия, Комсомольск-на-Амуре). E-mail: info@knaapo.com. Mr. Sergey P. Mazur - PhD in Engineering Science, chief welder, Sukhoi Company (PJSC) KnAAZ branch (Russia, Komsomolsk-on-Amur). E-mail: info@knaapo.com.

Муравьёв Василий Илларионович - доктор технических наук, профессор кафедры машиностроения и металлургии Комсомольского-на-Амуре государственного технического университета (Россия, Комсомольск-на-Амуре). E-mail: mim@knastu.ru.

Mr. Vasiliy I. Muravyev - Doctor of Engineering, professor of Komsomolsk-on-Amur State Technical University (Russia, Komsomolsk-on-Amur).E-mail:mim@knastu.ru.

Ковалёв Виталий Андреевич - студент Комсомольского-на-Амуре государственного технического университета (Россия, Комсомольск-на-Амуре). E-mail: mim@knastu.ru.

Mr. Vitaliy A. Kovalev - a student of Komsomolsk-on-Amur State Technical University (Russia, Komsomolsk-on-Amur). E-mail: mim@knastu.ru.

Аннотация. Проведены исследования влияния частоты импульса сварочной дуги на структуру и свойства сварных соединений алюминиевых трудопроводных систем, выполненных ручной аргонодуговой сваркой неплавящимся вольфрамовым электродом с присадком на установке MasterTig3500. Выявлено, что частота импульсов сварочного тока играет существенную роль в формообразовании сварного соединения. Определены оптимальные значения частоты сварочного тока, существенно ускоряющие процесс сварки с обеспечением стабильного качества сварного шва. Уточнены некоторые особенности процесса очистки деталей металлической щёткой перед сваркой.

Summary . The article focuses on the arc impulse frequency effect on the structure and properties of welded connections in aluminum pipeline systems hand-operated with argon-arc welding nonconsumable rod on MasterTig3500. It was revealed that the frequency of the welding current impulses plays an important role in the forming of the welded connection. The authors determined the optimal value of the welding current frequency significantly accelerating the welding process to ensure consistent quality of the weld. The authors detailed some features of cleaning assembly parts with a wire brush prior to welding process.

Ключевые слова: сварка, алюминиево-магниевые сплавы, пористость.

Key words: welding, aluminum-magnesium alloys, porosity. 
УДК 621.791

\section{Введение}

На предприятии КнААЗ им. Ю. А. Гагарина (г. Комсомольск-на-Амуре) трубопроводные системы из алюминиевых сплавов АМг2М, АМг3, АМг6, ВАЛ 5 свариваются преимушественно аргонодуговой электросваркой неплавящимся электродом (TIG) c применением современного сварочного оборудования фирмы Kemppi (Финляндия) MasterTig3500. Эта установка имеет достаточно широкий диапазон регулирования частоты импульса тока $(50-200$ Гц), но сварщики не всегда применяют это преимущество. Тем не менее из работ $[1 ; 2 ; 3 ; 4]$ известно, что повышение частоты импульса тока способствует улучшению качества сварных соединений. Вместе с тем процент сдачи деталей с первого предъявления по данным рентгеновского контроля не превышает 60 - $65 \%$, остальные 35 40 \% деталей подвергаются исправлению (причём в ряде случаев неоднократному): разделка дефекта, подварка, рентгенографический контроль. Значительная дефектность процесса сварки трубопроводов приводит к неритмичности производства трубопроводов, что в свою очередь удлиняет циклы сборки самолётов [5]. Поэтому исследования влияния частоты импульса сварочной дуги на структуру и свойства сварного соединения элементов алюминиевых трудопроводных систем, выполненных ручной аргонодуговой сваркой неплавящимся вольфрамовым электродом с присадком на установке MasterTig3500, является весьма актуальной задачей.

\section{Методика проведения исследований}

Изготовлены 4 образца патрубка, имеющие стыковое соединение без скоса кромок. Размеры образцов: диаметр 60 мм, толщина стенки 1,0 мм, общая длина 150 мм. Сборка и сварка проводились по базовой технологии: соединение по ПИ 1.4.1555-85 «Сварка в среде инертных газов» С00000 без скоса кромок (см. табл. 1), без сварочной оснастки, сборка в сборочном приспособлении с предварительной постановкой прихваток (3 шт.) и механической обработкой кромок металлической щёткой, с гашением дуги для поворота детали, число свареных секторов - 4, сварное соединение имело нижнее положение. Химическая подготовка деталей под сварку осуществлялась по заводской технологии.

Ориентировочные режимы сварки: $I_{\text {св }}=60 \mathrm{~A}, U_{\text {д }}=20-30 \mathrm{~B}, V_{\text {св }}=2,5 \mathrm{M} / \mathrm{4}, Q=8$ л/м, время продувки до сварки 5 с, после сварки - 10 с.

Таблица 1

Конструктивные элементы и размеры сварных соединений по ПИ 1.4.1555-2005

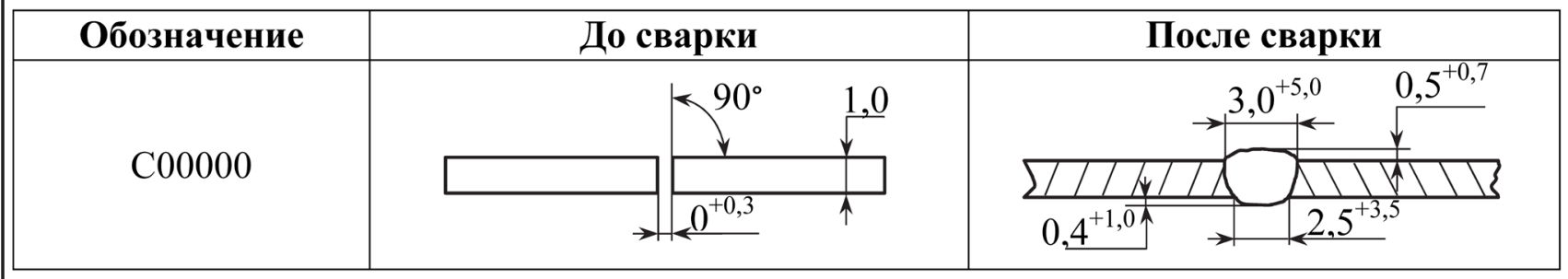

При формировании сварных швов образцов варьировалась частота импульса сварочного тока:
Образец 1
Образец 2
Образец 3
Образец 4
$50 \Gamma_{ц}$
$100 \Gamma_{ц}$
$150 \Gamma_{ц}$
$200 \Gamma_{ц}$

Сварочные материалы: электрод вольфрамовый СВИ-1, диаметр 2 мм; присадочная проволока Св-АМг3 диаметр 1,6 мм; аргон высшей чистоты.

Сварку производил один сварщик: 5 разряд, опыт работы на участке сварки алюминиевого трубопровода - 16 лет, личный коэффициет брака - $1 \%$, процент деталей удовлетворительного качества с первого предъявления - 48 \%. 
Бахматов П. В., Мазур С. П., Муравьёв В. И., Ковалёв В. А.

ИССЛЕДОВАНИЕ ВЛИЯНИЯ ЧАСТОТЫ ИМПУЛЬСА СВАРОЧНОЙ ДУГИ НА СТРУКТУРУ И СВОЙСТВА СВАРНЫХ СОЕДИНЕНИЙ ЭЛЕМЕНТОВ АЛЮМИНИЕВЫХ ТРУБОПРОВОДНЫХ СИСТЕМ, ВЫПОЛНЕННЫХ НА УСТАНОВКЕ МАSTЕRТІG 3500

Использовалась следующая техника формирования сварного шва с диапазоном поперечных колебаний $\pm 1,5$ мм от оси шва:

\section{Результаты исследований}

Сварка на 50 Гц не способствует хорошему разрушению окисной плёнки, затруднено формирование валика, что приводит к сварке на пониженных скоростях. Сварка с частотой импульса тока 100 Гц значительно улучшает, по отношению к 50 Гц, разрушение оксидной плёнки, стабилизирует процесс сварки. Применение импульса тока с частотой 150 Гц приводит к оптимальному качеству сварного соединения, улучшает разрушение оксидной плёнки, процесс формирования сварного шва становится более наблюдаемым.

200 Гц ведёт к повышенному расходу проволоки и увеличению скорости сварки. Приходится интенсивно контролировать формирование сварного соединения и внимательно следить за скоростью сварки. Повышенная частота импульсов увеличивает шумовой эффект от процесса сварки. Некомфортно работать на таких режимах без специальной защиты слухового аппарата.

После сварки образцы (см. рис. 1) подвергнуты визуально-измерительному и рентгенографическому контролю, а также исследованиям механических свойств и микроструктурному анализу сварных соединений.

a)

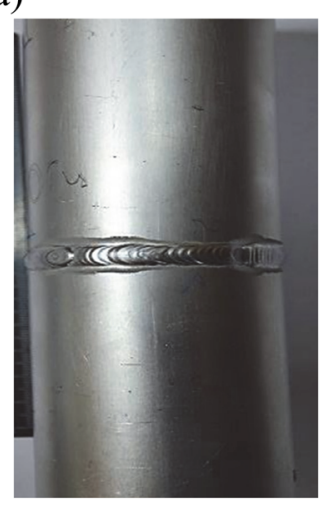

б)

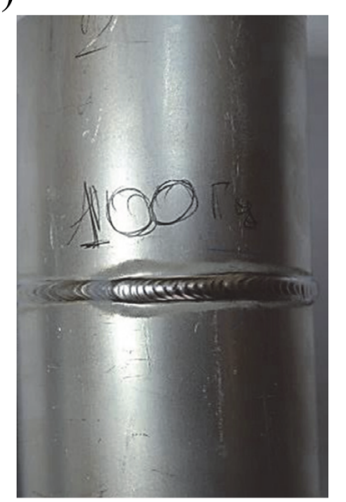

B)

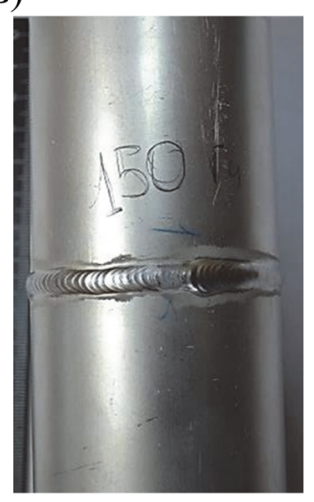

г)

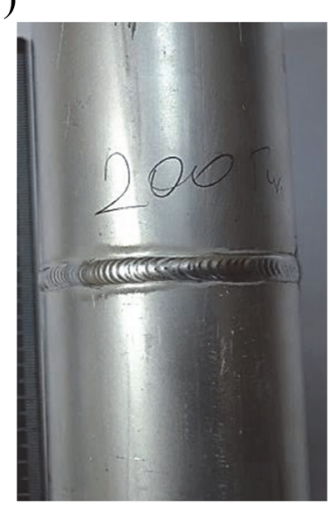

Рис. 1. Полученные сварные образцы: а - образец 1; б - образец 2; в - образец $3 ;$ г - образец 4

Внешний вид обнаруженных поверхностных дефектов после визуального осмотра сварных швов приведён в табл. 2.

Как видно из табл. 2, образец 3 имеет блестящую поверхность шва, равномерную чешуйчатость, на его поверхности отсутствуют визуально определяемые дефекты. Образцы 2 и 4 имеют единичные поры, расположенные на галтели - месте перехода усиления шва к лицевой поверхности основного металла. Согласно ПИ 1.4.1555-2000, поры, раковины, вольфрамовые, неметаллические и флюсовые включения, выходящие на поверхность шва, являются недопустимым дефектом вне зависимости от категории сварного соединения. Этот дефект может появиться по причине недостаточной очистки поверхности от окисной плёнки и/или других загрязнений. Образец 1 имеет поверхностную рыхлотность, проходящую преимущественно по центру сварного шва и распространяюшуюся на $1 / 3$ от всей его длины. В этом месте, судя по отсутсвию чешуйчатости, сваршик пытался исправить дефекты шва, проходя дугой без присадки. Судя по результату, ему это не удалось. Вероятная причина образования этого дефекта - загрязнения сварочной проволоки и/или недостаточная защита газом. 


\begin{tabular}{|c|c|c|c|}
\hline \multirow{2}{*}{\multicolumn{4}{|c|}{ Обнаруженные поверхностные дефекты сварных соединений }} \\
\hline & & & \\
\hline Образец & Изображение шва & Описание дефекта & $\begin{array}{c}\text { Качество поверхности } \\
\text { шва }\end{array}$ \\
\hline 1 & & $\begin{array}{l}\text { Рыхлоты на поверх- } \\
\text { ности сварного шва }\end{array}$ & $\begin{array}{l}\text { Поверхность шва } \\
\text { матовая }\end{array}$ \\
\hline 2 & & $\begin{array}{l}\text { Единичная пора } \\
\text { в галтеле, превы- } \\
\text { шение усиления } \\
\text { замка }\end{array}$ & $\begin{array}{l}\text { Поверхность шва } \\
\text { матовая }\end{array}$ \\
\hline 3 & ब@ & $\begin{array}{l}\text { Поверхностных } \\
\text { дефектов не обна- } \\
\text { ружено }\end{array}$ & $\begin{array}{l}\text { Равномерная } \\
\text { чешуйчатость, } \\
\text { блестящая поверхность } \\
\text { шва }\end{array}$ \\
\hline 4 & & $\begin{array}{l}\text { Единичная пора } \\
\text { в галтеле }\end{array}$ & $\begin{array}{l}\text { Поверхность шва } \\
\text { блестящая, равномерная } \\
\text { чешуйчатость }\end{array}$ \\
\hline
\end{tabular}

Проведёные измерения ширины шва и высоты усиления при помощи металлической линейки и универсального шаблона сварщика УШС-3 показали удовлетворительное качество геометрии швов.

Результаты рентгенографического контроля приведены в табл. 3. На каждый сварной образец было сделано по 2 снимка с диаметральным расположением источника излучения. Схема проведения контроля ГОСТ 7512-82-5г.

Таблица 3

Дефекты, выявленные рентгенографическим контролем

\begin{tabular}{|c|c|c|c|}
\hline \multirow[t]{2}{*}{ Образец } & \multicolumn{2}{|c|}{ Снимок } & \multirow{2}{*}{$\begin{array}{l}\text { Описание } \\
\text { дефектов }\end{array}$} \\
\hline & 1 & 2 & \\
\hline 1 & & & $\begin{array}{l}\text { Удовлетворитель- } \\
\text { но, недопустимых } \\
\text { дефектов не вы- } \\
\text { явлено }\end{array}$ \\
\hline 2 & & & $\begin{array}{l}4 \text { единичных поры } \\
\text { по галтеле, диа- } \\
\text { метр каждой } \\
0,2 \text { мм }\end{array}$ \\
\hline 3 & & & $\begin{array}{l}\text { Единичная пора, } \\
\text { диаметр 0,5 мм }\end{array}$ \\
\hline 4 & & & $\begin{array}{l}\text { Единичная пора, } \\
\text { диаметр } 1 \text { мм }\end{array}$ \\
\hline
\end{tabular}

Из данных табл. 3 видно, что по результатам рентгенографического контроля требованиям ПИ 1.4.1555-200 удовлетворяет образец 1. Остальные имеют внутренние недопустимые для первой категории шва дефекты. 
Бахматов П. В., Мазур С. П., Муравьёв В. И., Ковалёв В. А.

ИССЛЕДОВАНИЕ ВЛИЯНИЯ ЧАСТОТЫ ИМПУЛЬСА СВАРОЧНОЙ ДУГИ НА СТРУКТУРУ И СВОЙСТВА СВАРНЫХ СОЕДИНЕНИЙ ЭЛЕМЕНТОВ АЛЮМИНИЕВЫХ ТРУБОПРОВОДНЫХ СИСТЕМ, ВЫПОЛНЕННЬХ НА УСТАНОВКЕ МАSTЕRТІG 3500

Исследования механических свойств проводили на разрывной машине Instron 3382 с использованием экстензометра. Скорость нагружения с тензометром 0,5 мм/мин, до 1,5 \% удлинения, далее без тензометра - 10 мм/мин. Испытаниям подверглись образцы поперечного разреза сварного шва по ГОСТ 10006-80 (см. рис. 2) по два с каждого сварного соединения. Параметры образцов: ширина $-10 \times 150 x 1,0$ мм, $L_{\mathrm{p}}=55$ мм. Результаты проведённых исследований приведены в табл. 4.

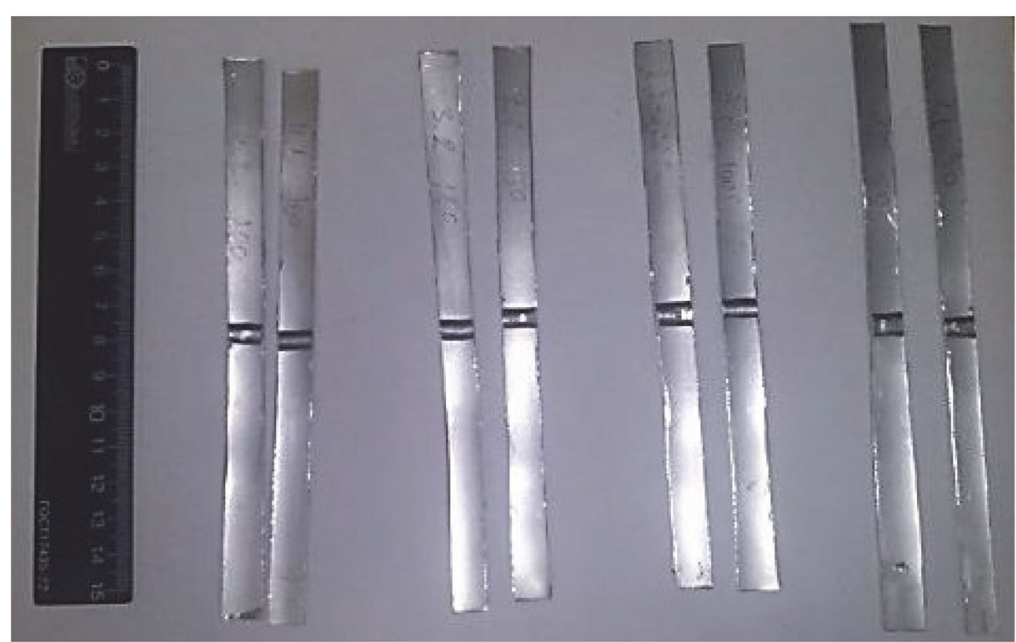

Рис. 2. Образцы, подготовленные к испытанию на статическое растяжение

Анализ результатов испытаний сварных образцов на статическое растяжение показал, что сварные соединения выдерживают нагрузку, т.к. разрушение всех образцов произошло по основному металлу. При этом предел прочности образцов не превысил 174 МПа, а относительное удлинение - $31 \%$.

По ГОСТ 4784-97 значения механических свойств для труб ГОСТ 18482-79 следующие: $\sigma_{\mathrm{B}}=155 \mathrm{MПа;} \sigma_{\mathrm{T}}=60 \mathrm{MПа;} \delta=10 \%$. Таким образом, все образцы соответствуют требованиям, предъявляемым к основному металлу.

Таблица 4

Результаты испытаний сварных образцов на статическое растяжение

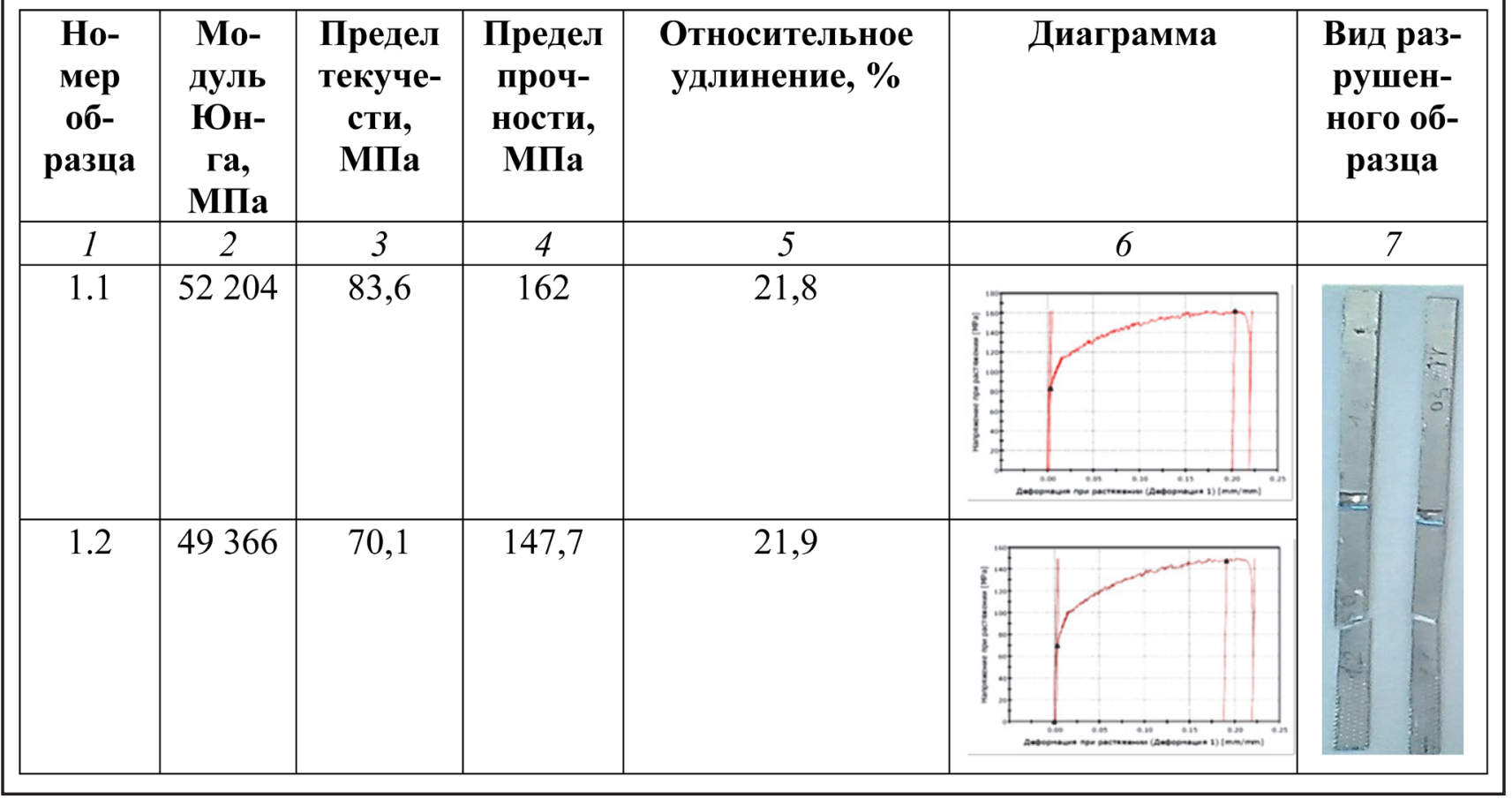




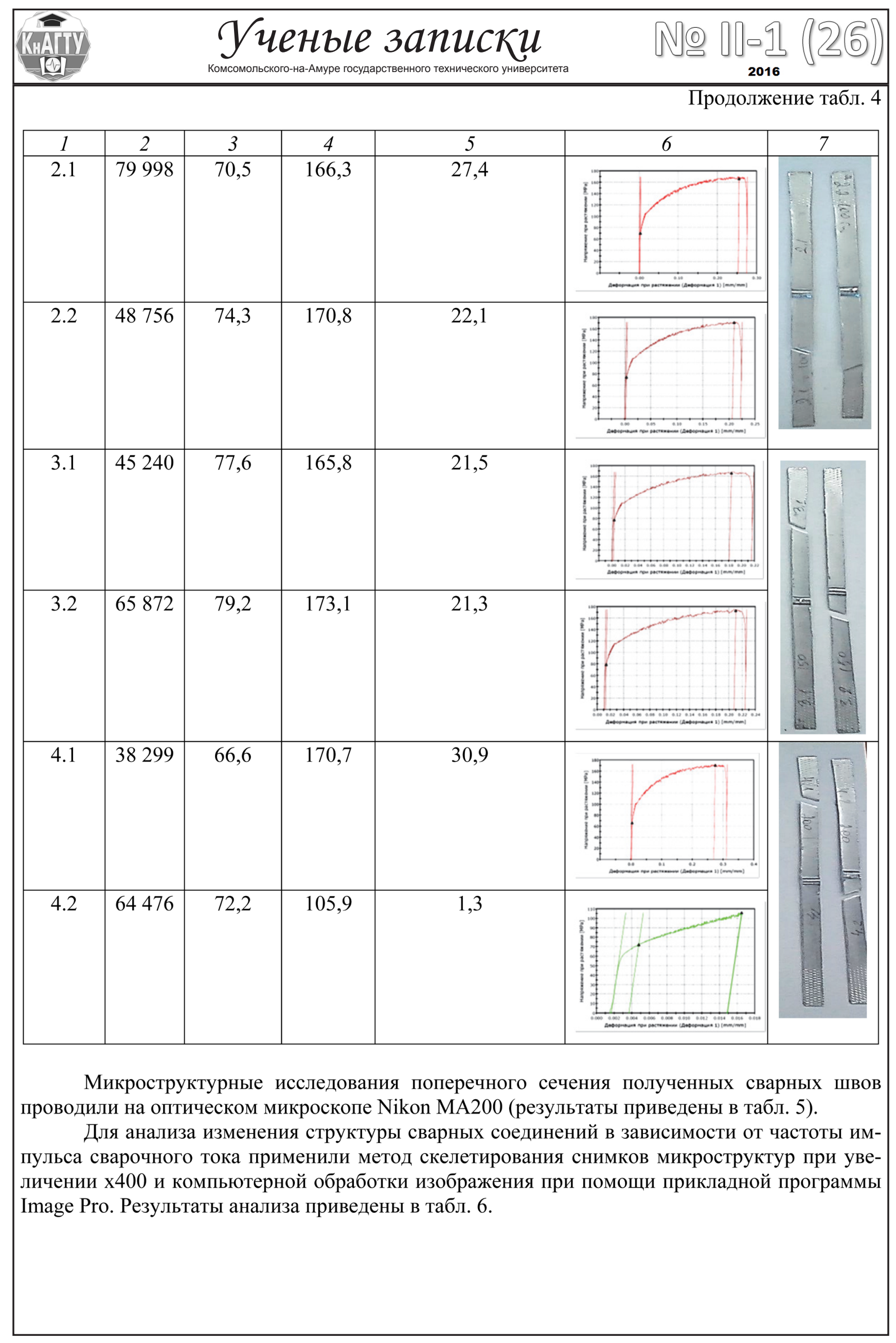


Бахматов П. В., Мазур С. П., Муравьёв В. И., Ковалёв В. А.

ИССЛЕДОВАНИЕ ВЛИЯНИЯ ЧАСТОТЫ ИМПУЛЬСА СВАРОЧНОЙ ДУГИ НА СТРУКТУРУ И СВОЙСТВА СВАРНЬХ СОЕДИНЕНИЙ ЭЛЕМЕНТОВ АЛЮМИНИЕВЫХ ТРУБОПРОВОДНЫХ СИСТЕМ, ВЫПОЛНЕННЫХ НА УСТАНОВКЕ МАSTЕRТІG 3500

Микроструктура сварных соединений, х100

Таблица 5

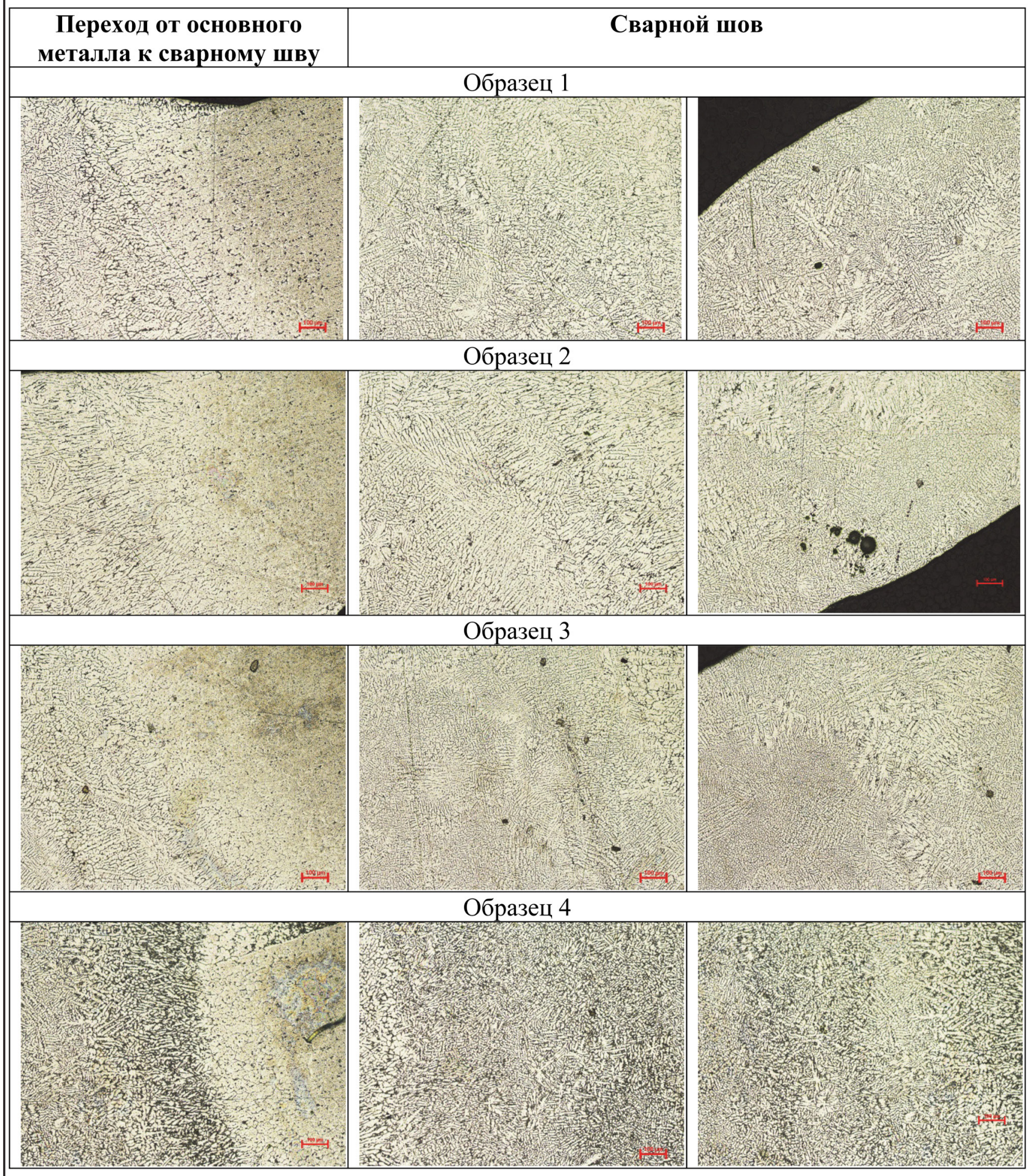




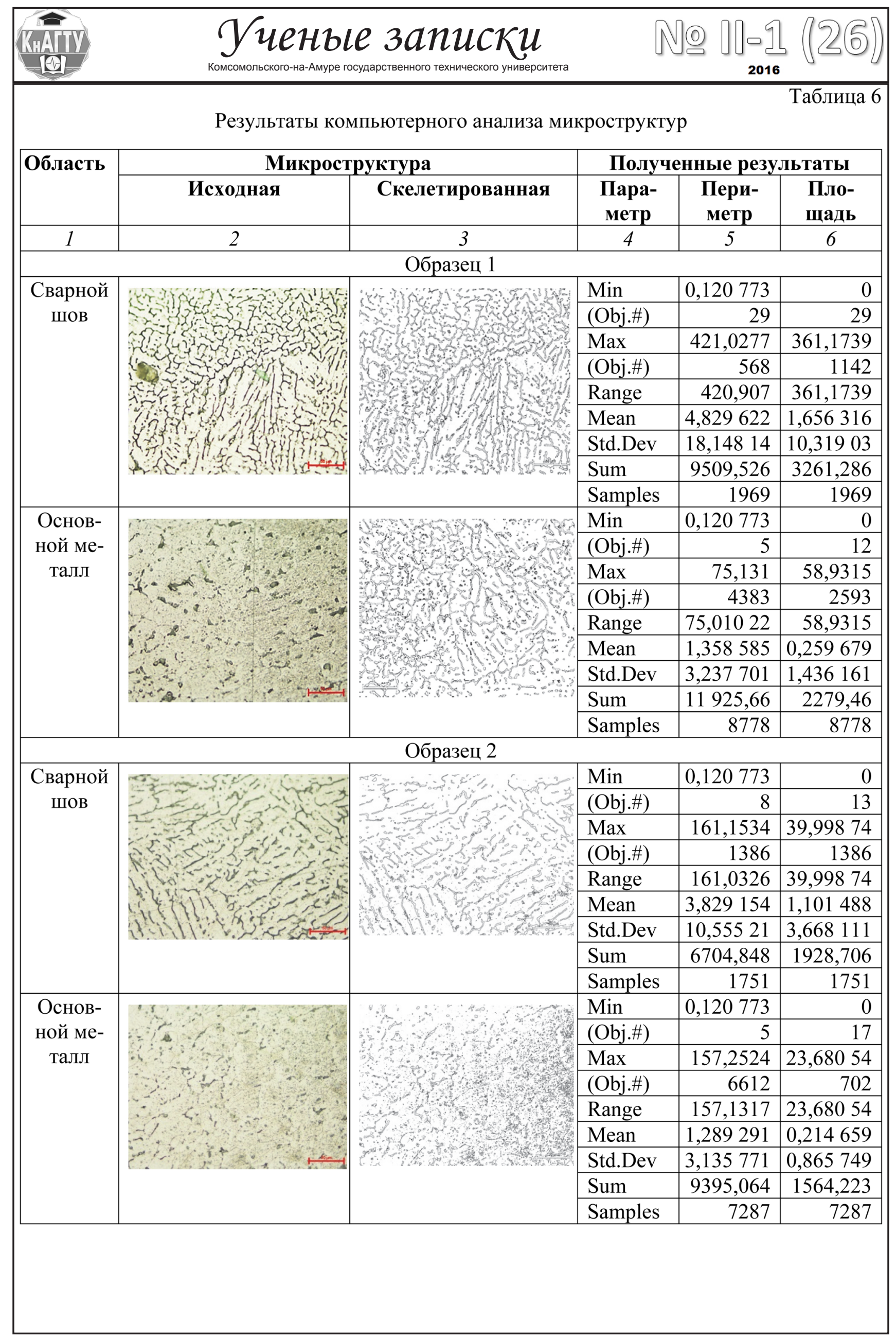


Бахматов П. В., Мазур С. П., Муравьёв В. И., Ковалёв В. А.

ИССЛЕДОВАНИЕ ВЛИЯНИЯ ЧАСТОТЫ ИМПУЛЬСА СВАРОЧНОЙ ДУГИ НА СТРУКТУРУ И СВОЙСТВА СВАРНЫХ СОЕДИНЕНИЙ ЭЛЕМЕНТОВ АЛЮМИНИЕВЫХ ТРУБОПРОВОДНЫХ СИСТЕМ, ВЫПОЛНЕННЫХ НА УСТАНОВКЕ МАSTЕRТІG 3500

Продолжение табл. 6

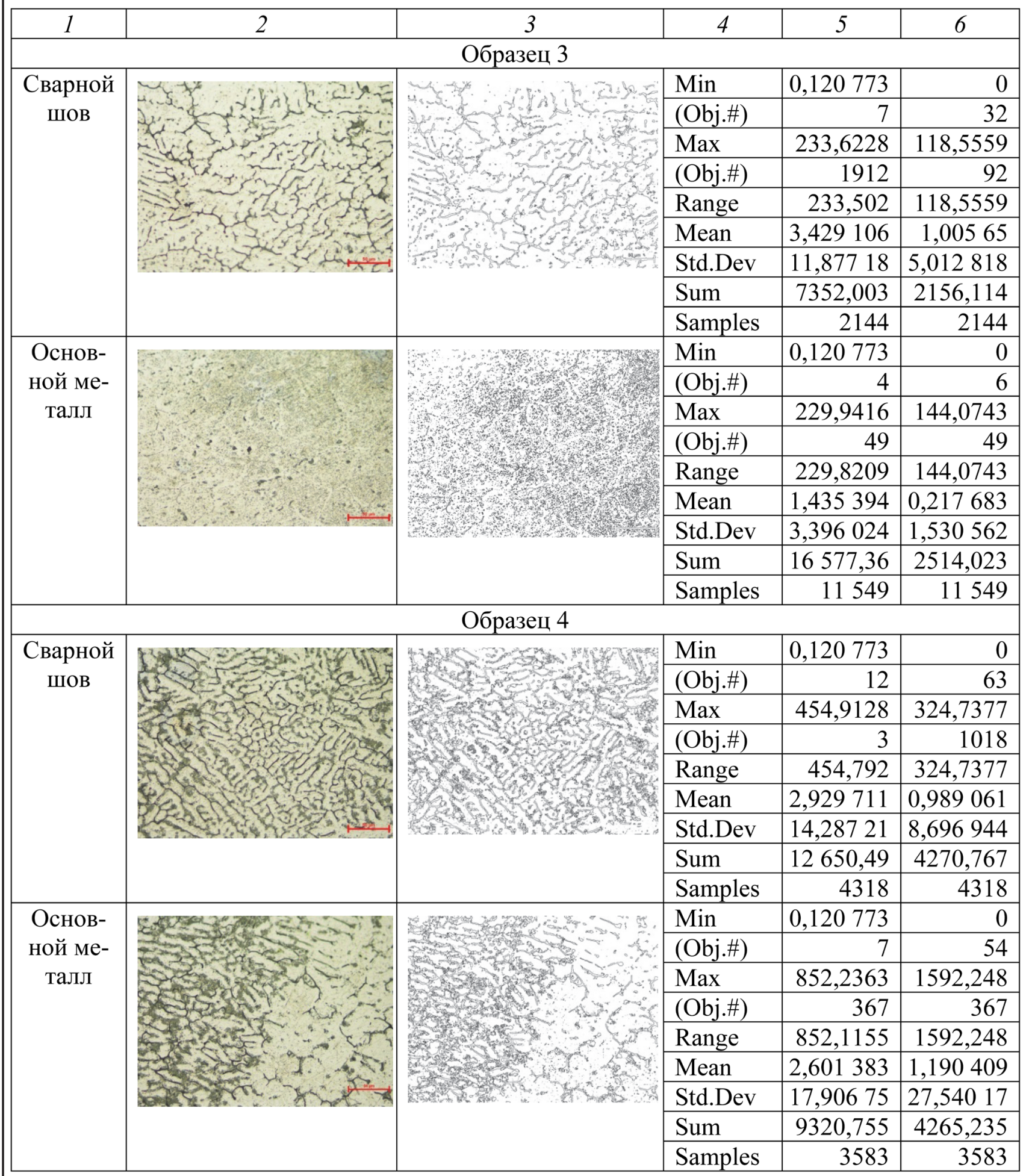

Свод расчётных данных по программе Image Pro приведён в табл. 7.

Как видно из табл. 6 и 7, периметр границ объектов, обнаруженных на микроснимке сварного шва, возрастает относительно основного металла, а средняя плотность границ зёрен увеличивается в 2 раза во всех образцах. Исключение составил образец 4.

Вообще возрастание средней плотности границ зёрен объясняется образованием дендритных структур сварного шва, имеющих меньшее количество и увеличенный объём (периметр). В отношении образца 4 можно сказать, что структура основного металла сходна со структурой сварного шва по количеству зёрен и их периметру. 


\begin{tabular}{|c|c|c|}
\hline (a) & Лuefble $3 \mathrm{anu}$ & NOO \\
\hline \multicolumn{3}{|c|}{ Расчётная средняя плотность границ зёрен } \\
\hline № образца & Область определения значений & Средняя плотность границ зёрен \\
\hline \multirow[t]{2}{*}{1} & Шов & 2,915882 \\
\hline & Основной металл & 5,231791 \\
\hline \multirow[t]{2}{*}{2} & Шов & 3,476346 \\
\hline & Основной металл & 6,006216 \\
\hline \multirow[t]{2}{*}{3} & Шов & 3,40984 \\
\hline & Основной металл & 6,593959 \\
\hline \multirow[t]{2}{*}{4} & Шов & 2,962113 \\
\hline & Основной металл & 2,185285 \\
\hline
\end{tabular}

Кроме основных исследований произвели анализ поверхности щетинок металлической щётки, используемой в операции подготовки кромок под сварку, и качества поверхности основного металла и сварочной проволоки.

На поверхности рабочих торцов щетинок металлической щётки и на протяжении 1 мм от них обнаружены загрязнения (см. рис. 3), на остальных участках поверхность удовлетворительная.

Предположительно наблюдаемый объект - алюминий (по техническим причинам произвести химический анализ не удалось). Объяснить этот эффект можно нагревом за счёт сил трения алюминиевой части и переноса металла на более холодную стальную проволоку. Как видно из рис. 3, объём нанесённого слоя может быть существенным и постоянно взаимодействовать с очищаемым металлом. Таким образом, можно сделать вывод о том, что использование металлических щёток для подготовки поверхности кромок под сварку нецелесообразно, т.к. способствует перемещению оксидных загрязнений на всю обрабатываемую поверхность и не гарантирует полного их удаления.

a)

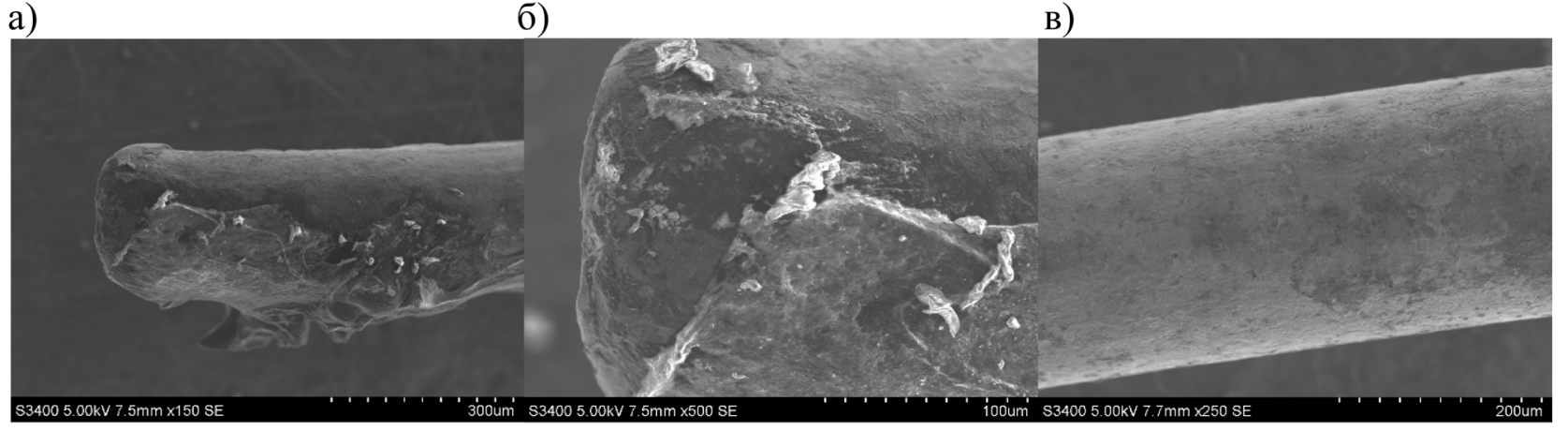

Рис. 3. Поверхности щетинок металлической щётки:

a, б - рабочий торец; в - центральная часть

Структура поверхности соединяемых кромок приведена в табл. 8. Исследование качества подготовки поверхности образцов производилось после сварки и на небольшом расстоянии от оси шва (10 - 15 мм).

Как видно из рис. 4, поверхность свариваемых кромок была химически подготовлена, о чём свидетельствуют каверны, остающиеся после травления. Но размытость промежутков между ними говорит об организации существенного оксидного слоя на ранее химобработанной поверхности. Этому способствовало значительное время между сваркой и анализом и повышенные температуры нагрева. Тем не менее на исследуемых образцах не обнаружены следы механической обработки металлическими щётками после травления. Что, в свою очередь, оправдывает наблюдаемые как поверхностные, так и внутренние дефекты сварных швов. 
Бахматов П. В., Мазур С. П., Муравьёв В. И., Ковалёв В. А.

ИССЛЕДОВАНИЕ ВЛИЯЯНИЯ ЧАСТОТЫ ИМПУЛЬСА СВАРОЧНОЙ ДУГИ НА СТРУКТУРУ И СВОЙСТВА СВАРНЫХ СОЕДИНЕНИИ ЭЛЕМЕНТОВ АЛЮМИНИЕВЫХ ТРУБОПРОВОДНЫХ СИСТЕМ, ВЫПОЛНЕННЫХ НА УСТАНОВКЕ МАSTЕRТIG 3500
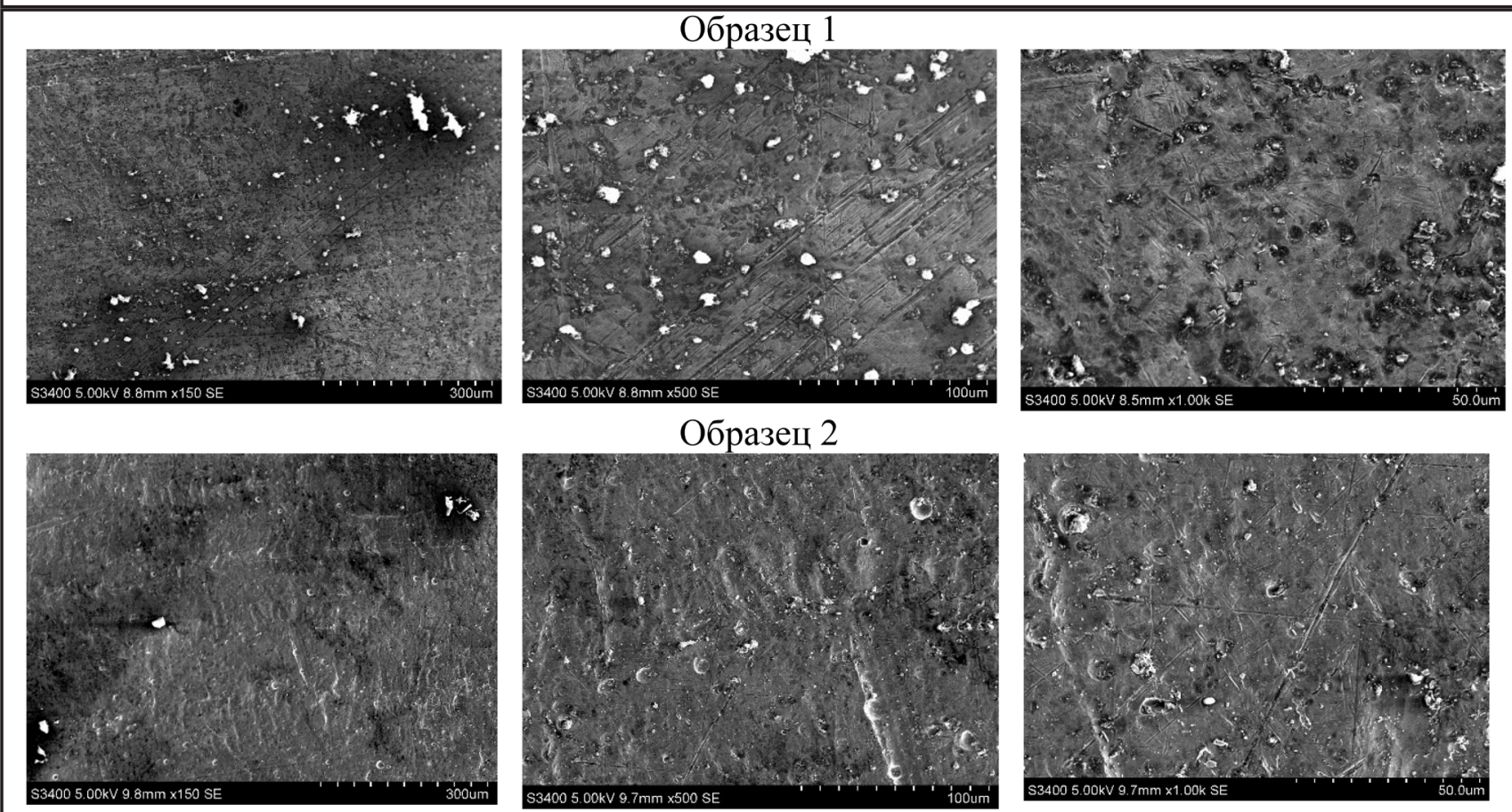

\section{Образец 3}
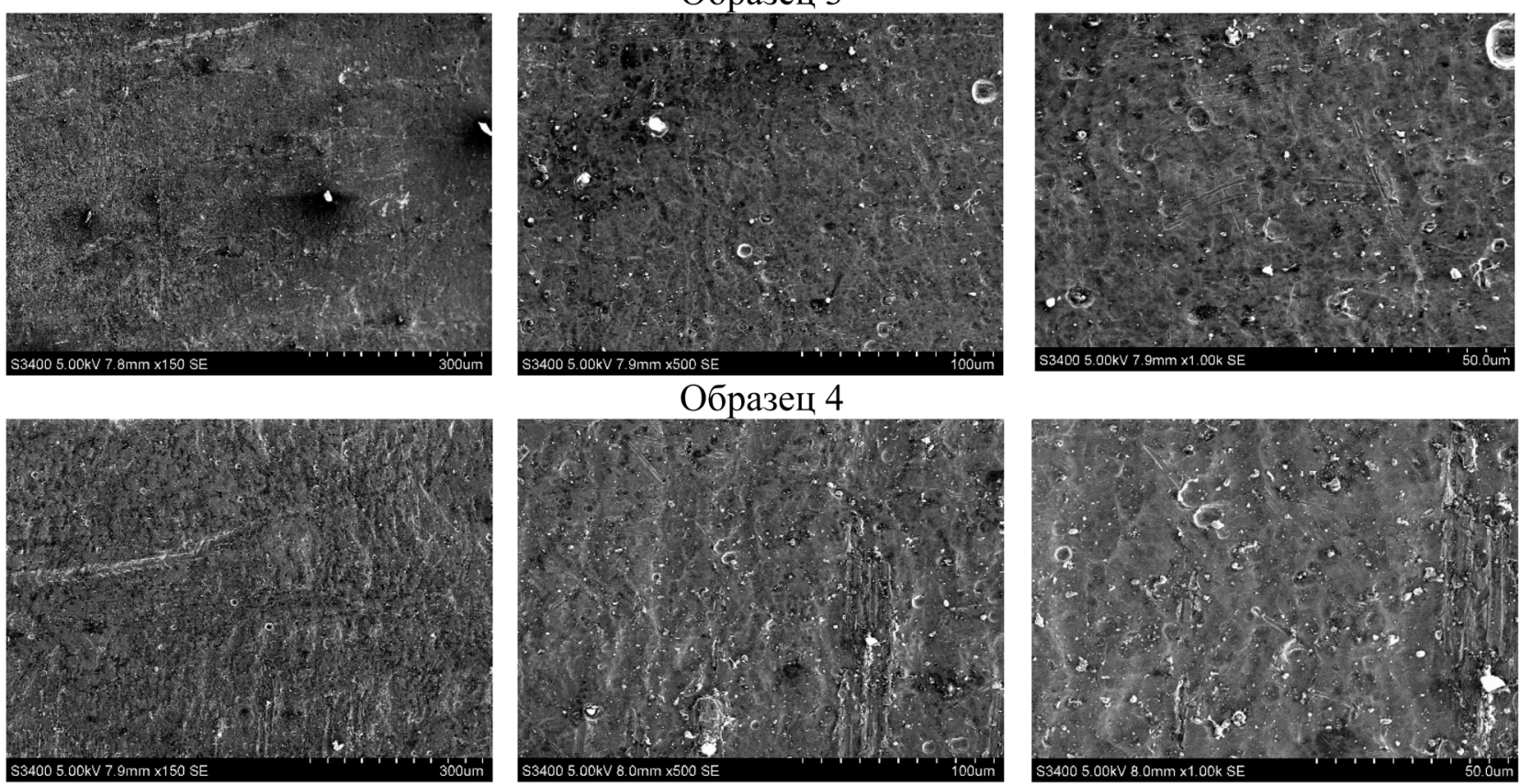

Рис. 4. Поверхность металла, прилегающая к торцам свариваемых образцов

a)

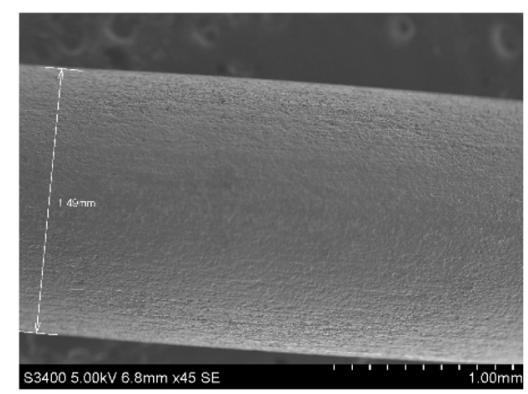

б)

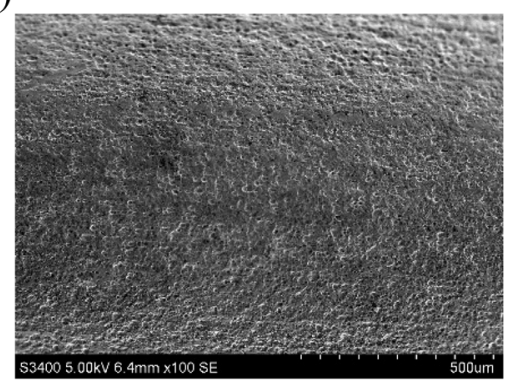

B)

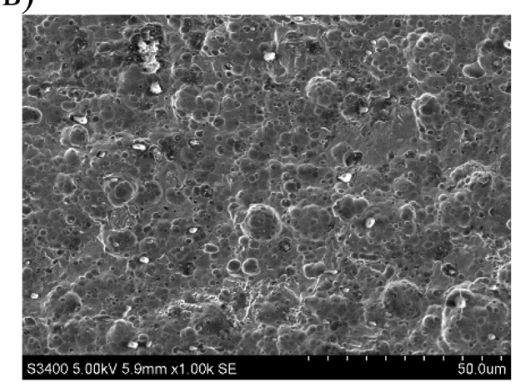

Рис. 5. Микроструктура поверхности сварочной проволоки: a - х45; б - х100; в - х1000 
На рис. 5 приведены данные по качеству поверхности сварочной проволоки, используемой при формировании образцов.

Как видно из рис. 5, качество сварочной проволоки соответствует требованиям времени травления по ПИ 1.4.1555-2000 и составляет $100-120$ с.

\section{Выводы:}

1. Частота импульсов сварочного тока играет существенную роль в формообразовании сварного соединения из алюминиевого сплава, определяя технологические параметры режима сварки. Пониженные значения частоты сварочного тока (ниже 75 Гц) недостаточны для эффективного разрушения оксидной плёнки и приводят к возникновению непроваров и поверхностных рыхлот, хотя сам процесс сварки по шуму комфортный. Повышение частоты до $100-150$ Гц приводит к улучшению и информативности процесса формирования сварного соединения, хотя и усугубляет шумовой фон. Частота 200 Гц существенно ускоряет разрушение поверхностной оксидной плёнки как основного, так и присадочного металла, обуславливая ускорение процесса сварки с обеспечением стабильного качества сварного шва.

2. Качество поверхности свариваемых деталей и сварочных материалов из алюминия и его сплавов играет решаюшую роль в образовании дефектов сварного соединения вне зависимости от режимов сварки, квалификации сварщика и применяемой техники формирования соединения.

3. Применение в технологическом процессе подготовки кромок под сварку металлических щёток не гарантирует полной очистки обрабатываемой ими поверхности от окисных плёнок и других загрязнений. Кроме того, вероятность нанесения на рабочую кромку щетинки алюминия способствует его интенсивному окислению и нанесению оксида на поверхность обрабатываемой кромки.

\section{ЛИТЕРАТУРА}

1. Вагнер, Ф. А. Оборудование и способы сварки пульсирующей дугой / Ф. А. Вагнер. - М.: Энергия, 1980. $-120 \mathrm{c}$.

2. Жерносеков, А. М. Импульсно-дуговая сварка плавящимся электродом (обзор) / А. М. Жерносеков, В. В. Андреев // Автоматическая сварка. - 2007. - № 10. - С. 48-52.

3. Becker, D. W. Investigation of Pulsed GTA welding parameters / D. W. Becker, Jr. C. M. Adams // Welding Journal. - 1978. - № 5. - P. 134-138.

4. Bosworth, M. R. Effective heat input in Pulsed Current Gas Metal Arc Welding with solid wire electrodes / M. R. Bosworth // Welding Journal. - 1991. - № 5. - P. 111-117.

5. Бахматов, П. В. Исследование причин и путей устранения порообразования в сварных соединениях элементов алюминиевого трубопровода / П. В. Бахматов, С. П. Мазур, В. И. Муравьёв // Учёные записки Комсомольского-на-Амуре гос. техн. ун-та. Науки о природе и технике. -2015 . - № III-1(23). C. 54-64. 